\title{
Effects of low molecular weight heparin and rivaroxaban on rat Achilles tendon healing
}

\author{
Düşük molekül ağırlıklı heparin ile rivaroksabanın sıçan Aşil tendonu iyileşmesi üzerindeki etkileri
}

\author{
Yılmaz Eren, MD, ${ }^{1}$ Oktay Adanır, MD, ${ }^{1}$ Yaşar Mahsut Dinçel, MD, ${ }^{1}$ Erdinç Genç, MD, ${ }^{1}$ \\ Yunus Ziya Arslan, MD, ${ }^{2}$ Aysel Çağlar, $\mathrm{MD}^{3}$ \\ ${ }^{1}$ Department of Orthopedics and Traumatology, Bağcılar Training and Research Hospital, İstanbul, Turkey \\ ${ }^{2}$ Department of Mechanical Engineering, İstanbul University, Faculty of Engineering, İstanbul, Turkey \\ ${ }^{3}$ Department of Pathology, Bağcılar Training and Research Hospital, İstanbul, Turkey
}

\begin{abstract}
Objectives: This study aims to compare the histopathological and biomechanical effects of low molecular weight heparin (LMWH) and rivaroxaban, which are frequently used in orthopedic surgery for thromboembolic prophylaxis, on rat Achilles tendon healing.

Materials and methods: In the study, 36 adult, male Sprague Dawley rats weighing between $300 \mathrm{~g}$ and $400 \mathrm{~g}$ were used. Three groups were formed including 12 rats in each. Achilles tendons of all rats were cut and repaired. Nadroparin calcium was administered subcutaneously for 21 days at a dose of 170 IU AXa to the first group (LMWH group). Rivaroxaban was administered daily at a dose of $3 \mathrm{mg} / \mathrm{kg}$ for 21 days as gastric lavage to the second group (rivaroxaban group). The third group was identified as the control group and no medication was administered in this group. At the end of three weeks, tendons extracted from the groups were examined histopathologically and biomechanically.
\end{abstract}

Results: Bonar's and Movin's scores obtained as a result of histopathological examination were statistically significantly higher in the control group ( $\mathrm{p}=0.003$ and $\mathrm{p}=0.004$, respectively) (high scores indicate that tendon healing is not sufficient). When type I and type III collagen ratios were examined, type I collagen ratio, which should be found at a higher ratio in mature tendon, was statistically significantly higher in rivaroxaban and LMWH groups compared with the control group ( $\mathrm{p}=0.002)$. As a result of biomechanical examination, higher mean maximum force values were obtained from the rivaroxaban group compared with the LMWH group $(\mathrm{p}=0.31)$. Mean maximum force values obtained from the control group were higher than those obtained from the LMWH group ( $\mathrm{p}=0.03)$ and the rivaroxaban group $(\mathrm{p}=0.18)$.

Conclusion: Histopathological examination revealed that both LMWH and rivaroxaban have positive effects on tendon healing. However, the same positive effects were not detected in biomechanical examination.

Keywords: Achilles tendon; low molecular weight heparin; rat; rivaroxaban.

\section{ÖZ}

Amaç: $\mathrm{Bu}$ çalışmada ortopedik cerrahide tromboemboli profilaksisi için sık kullanılan düşük molekül ağırlıklı heparin (DMAH) ve rivaroksabanın, sıçan Aşil tendonu iyileşmesi üzerindeki histopatolojik ve biyomekanik etkileri karşılaştırıldı.

Gereç ve yöntemler: Çalışmada yetişkin, ağırlıkları 300 g-400 g arasında değişen 36 erkek Sprague Dawley sıçan kullanıldı. Her grupta 12 sıçan olacak şekilde üç grup oluşturuldu. Tüm sıçanların Aşil tendonları kesilip tamir edildi. Birinci gruba (DMAH grubu) 21 gün süreyle 170 IU AXa dozunda nadroparin kalsiyum subkütan olarak verildi. İkinci gruba (rivaroksaban grubu) ise 21 gün süreyle $3 \mathrm{mg} / \mathrm{kg}$ dozunda rivaroksaban günlük gastrik lavaj olarak verildi. Üçüncü grup kontrol grubu olarak belirlendi ve bu grupta herhangi bir ilaç uygulaması yapılmadı. Üç haftanın sonunda gruplardan alınan tendonlar histopatolojik ve biyomekanik açıdan incelendi.

Bulgular: Histopatolojik inceleme sonucunda elde edilen Bonar ve Movin skorları, kontrol grubunda istatistiksel olarak anlamlı şekilde daha yüksek idi (sırasılla, $\mathrm{p}=0.003$ ve $\mathrm{p}=0.004$ ) (skorların yüksek olması tendon iyileşmesinin yeterli olmadığını gösterir). Tip I ve tip III kollajen oranları incelendiğinde, matür tendonda daha yüksek oranda bulunması gereken tip I kollajen oranı, rivaroksaban ve DMAH gruplarında, kontrol grubuna kıyasla istatistiksel olarak anlamlı şekilde daha yüksek idi ( $\mathrm{p}=0.002)$. Biyomekanik inceleme sonucunda rivaroksaban grubundan, DMAH grubuna kıyasla daha yüksek ortalama maksimum kuvvet değerleri elde edildi ( $\mathrm{p}=0.31$ ). Kontrol grubundan elde edilen ortalama maksimum kuvvet değerleri, DMAH grubundan ( $\mathrm{p}=0.03$ ) ve rivaroksaban grubundan $(\mathrm{p}=0.18)$ elde edilenlerden daha yüksek idi.

Sonuç: Histopatolojik inceleme, hem DMAH'ın hem de rivaroksabanın tendon iyileşmesine olumlu etkileri olduğunu gösterdi. Ancak aynı olumlu etkiler biyomekanik incelemede tespit edilmedi.

Anahtar sözcükler: Aşil tendonu; düşük molekül ağırlıklı heparin; sıçan; rivaroksaban.

- Received: January 13, 2017 Accepted: November 08, 2017

- Correspondence: Oktay Adanır, MD. Bağcılar Eğitim ve Araştırma Hastanesi Ortopedi ve Travmatoloji Kliniği, 34100 Bağcılar, istanbul, Turkey. Tel: +90 532 - 6825177 e-mail: droktayadanir@yahoo.com 
Due to the increased interest in sports and the increased trauma frequency, Achilles tendon rupture rate has been increasing. Recently, incidence of Achilles tendon rupture has been reported as 62.9/100.000. ${ }^{[1]}$ Because of complications like prolonged postoperative recovery time, skin necrosis and infection around the surgical site and re-rupture; Achilles tendon injury is a significant health issue for middle-aged adults and athletes. ${ }^{[2]}$

Immobilization of the leg in the cast during conservative treatment or after the surgery and/or the effect of the trauma may result in deep venous thrombosis (DVT) after Achilles tendon rupture. ${ }^{[3]}$ In the literature, incidence of DVT after Achilles tendon injury has been reported between 1-34\%. ${ }^{[4-6]}$ Main topics for thromboembolism prophylaxis in hip and knee surgeries have been defined; however, there is no consensus on DVT prophylaxis after below-knee surgeries, which require immobilization. ${ }^{[7]}$ Nevertheless, a meta-analysis suggests routine prophylaxis after Achilles tendon injuries in order to decrease the risk of DVT and pulmonary thromboembolism (PE). ${ }^{[8]}$

Several studies on tendon healing exist in the literature. ${ }^{[9-11]}$ One of the main topics studied is the effect of anti-thrombotic agents on tendon healing. ${ }^{[12-14]}$ Yet, the number of these studies is limited and effect of specifically rivaroxaban on tendon healing has not been investigated. Therefore, in this study, we aimed to compare the histopathological and biomechanical effects of low molecular weight heparin (LMWH) and rivaroxaban, which are frequently used in orthopedic surgery for thromboembolic prophylaxis, on rat Achilles tendon healing.

\section{MATERIALS AND METHODS}

The study protocol was approved by the Local Ethics Committee for Animal Experiments of Istanbul Bagcilar Training and Research Hospital [06.08.2015 (2015/98)]. The study was conducted between October 2015 and November 2015 in accordance with the principles of the Declaration of Helsinki. Thirty-six adult, male Sprague-Dawley rats weighing between $300 \mathrm{~g}$ - $400 \mathrm{~g}$ were separated into three groups, each consisting of 12 rats. First group received subcutaneous $170 \mathrm{IU}$ AXa $(0.02 \mathrm{~mL})$ nadroparine calcium (Fraxiparine, Glaxo SmithKline, Canada) as LMWH once daily for 21 days. Second group received $3 \mathrm{mg} / \mathrm{kg}$ rivaroxaban (Xarelto, Bayer HealthCare, Berlin, Germany) diluted in $2 \mathrm{~mL}$ of saline via gastric lavage once daily for 21 days. Third group was determined as the control group and received no medication. On the purpose of standardizing the groups, rats in the first group received $2 \mathrm{~mL}$ $0.9 \%$ sodium chloride $(\mathrm{NaCl})$ daily via gastric lavage, rats in the second group received subcutaneous $0.02 \mathrm{~mL} 0.9 \% \mathrm{NaCl}$ daily and rats in the third group received same doses of $0.9 \% \mathrm{NaCl}$ both via gastric lavage and subcutaneously.

Surgical procedure: $8 \mathrm{mg} / \mathrm{kg}$ gentamicin was administered subcutaneously for antibiotic prophylaxis. Surgical procedures were performed under general anesthesia. Inhaler anesthetic drug isoflurane (Forane, Abbott Laboratuvarlar1 İthalat İhracat Tic. Ltd. Şti., İstanbul, Turkey) was administered with $4 \%$ dosage for induction and $2 \%$ for maintenance. Right lower extremities of the rats were shaved and then approximately $1 \mathrm{~cm}$ longitudinal incision was performed under sterile condition on the Achilles tendon; the tendon was exposed and cut transversely from approximately $0.5 \mathrm{~cm}$ proximal to the side of Achilles tendon insertion site via no.11 scalpel (Plusmed, Trimpeks İth. İhr. Tur. ve Tic. A.Ş., İstanbul, Turkey). Incised Achilles tendon was then repaired with Kessler method by using an atraumatic PDO II 4/0 (Boz Tibbi Malzeme San. ve Tic. A.Ş., Ankara, Turkey) and the skin was sutured by $3 / 0$ propylene (Doğsan Tibbi Malzeme San A.Ş, Trabzon, Turkey) (Figure 1).

Postoperative pain management was performed by subcutaneous application of 3-5 $\mathrm{mg} / \mathrm{kg}$ of carprofen (Rimadyl,Pzifer, New York, USA) with12-hourintervals in the first 24 hours. No postoperative immobilization method was applied. Rats were fed with unlimited water and standard rodent food (ad libitum) and kept in $22^{\circ} \mathrm{C}$ of temperature and 12-hour dark-light cycle. During the first 24 hours, each cage consisted

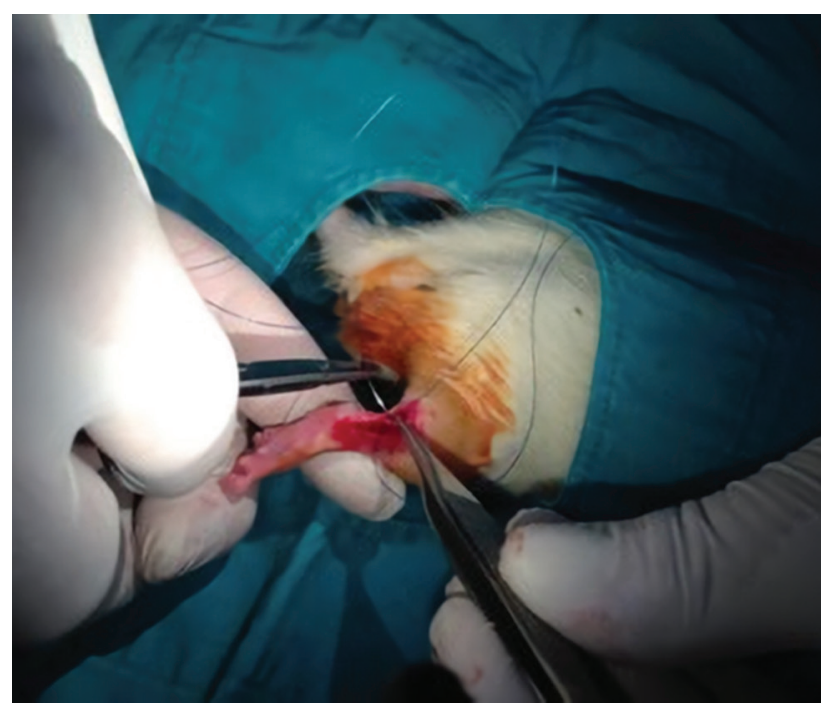

Figure 1. Repair of incised rat Achilles tendon. 




Figure 2. Tendon sample placed between jaws of tensile appliance during tendon tensile test.

of one rat; in the subsequent days, each cage consisted of six rats. Daily wound site assessment; general condition and physical activity were checked and recorded. After 21 days, euthanasia was performed through high dose anesthesia $(10 \mathrm{mg} / \mathrm{kg}$ Xylazine and $90 \mathrm{mg} / \mathrm{kg}$ ketamine-hydrochloride).

For histopathological assessments, six tendons from each group were extracted from adhesion site to calcaneus and femoral condyles. The tendons were fixated in $10 \%$ formaldehyde containers and embedded in paraffin blocks, then $4 \mu \mathrm{m}$ sequences were cut and hematoxylin-eosin, Mason's trichrome and Alcian Blue (pH 2.5) stains were applied to each block. Olympus BX51 light microscope was used for analyses. Histochemical assessment of type I/type III collagen staining pattern were performed with Sirius Red staining and x400 magnification. Semi-quantitative Movin's scale and semi-qualitative Bonar's scale were used for evaluation.

In Movin's semi-quantitative scale, all variables are scored between 0 and 3 (0: normal, 1: mildly abnormal, 2: abnormal, 3: significantly abnormal). Total semi-quantitative histological score can be determined between 0 (normal tendon) and 24 (most severely abnormal tendon). ${ }^{[15]}$ All variables in Bonar's scale are scored between 0 and 3. Total Bonar score can be determined between 0 (normal tendon) and 12 (most severely abnormal tendon). ${ }^{[16]}$

Tension test was applied on tendons for biomechanical evaluation. In order to perform that, six tendons from each group, which were not taken into histological assessment, were extracted from the insertion sites without plantaris tendon. Tendons were delivered to Machine Materials Laboratory of Istanbul University, Faculty of Mechanical Engineering in $0.9 \% \mathrm{NaCl}$ solution with a fair amount of bone from calcaneus on the distal side and muscle tissue on the proximal side.

Universal tensile application device (Instron 5982 universal testing machine, Norwood, MA, USA) was used for biomechanical tests. Load capacity of the appliance is $100 \mathrm{kN}$, speed range $0.00005-50 \mathrm{~mm} /$ minute, sampling frequency is $1 \mathrm{kHz}$ and load measurement accuracy is $\pm 0.5 \%$.

With the aim of sustaining a good grasp, distal bone tissues and proximal muscle tissues were attached and covered with emery paper, and then tendons were engaged to the jaws of the device from the emery paper covered surfaces. Tendon-emery paper contact was enabled by the utilization of cyanoacrylate glues. Samples were stretched longitudinally with a speed of $6 \mathrm{~mm} /$ minute until they ruptured. In order to determine and correlate the biomechanical endurance of the tendons, tensile force was applied until the tendons ruptured and the maximum tensile force value during the tendons ruptured was recorded (Figure 2).

\section{Statistical analysis}

Mean and standard deviation values were utilized to analyze descriptive data. Distribution of the variables was measured with KolmogorovSmirnov test. Nonparametric histopathological qualitative data were analyzed with Kruskal-Wallis

TABLE I

Statistical analyses of Bonar's scale results

\begin{tabular}{|c|c|c|c|c|c|c|c|c|c|c|}
\hline \multirow[b]{2}{*}{ Bonar's scale } & \multicolumn{3}{|c|}{ Control group } & \multicolumn{3}{|c|}{ Rivaroxaban group } & \multicolumn{3}{|c|}{ LMWH group } & \multirow[b]{2}{*}{$p$} \\
\hline & Mean $\pm S D$ & Median & Min-Max & Mean $\pm S D$ & Median & Min-Max & Mean $\pm S D$ & Median & Min-Max & \\
\hline Tenocytes & $1.7 \pm 0.5$ & 2.0 & $1.0-2.0$ & $1.2 \pm 0.4$ & 1.0 & $1.0-2.0$ & $1.0 \pm 0.0$ & 1.0 & $1.0-1.0$ & 0.033 \\
\hline Ground substance & $2.2 \pm 0.4$ & 2.0 & $2.0-3.0$ & $1.5 \pm 0.5$ & 1.5 & $1.0-2.0$ & $1.5 \pm 0.5$ & 1.5 & $1.0-2.0$ & 0.033 \\
\hline Collagen & $2.2 \pm 0.4$ & 2.0 & $2.0-3.0$ & $1.2 \pm 0.4$ & 1.0 & $1.0-2.0$ & $1.3 \pm 0.5$ & 1.0 & $1.0-2.0$ & 0.010 \\
\hline Vascularity & $3.0 \pm 0.0$ & 3.0 & $3.0-3.0$ & $1.8 \pm 1.0$ & 1.5 & $1.0-3.0$ & $1.7 \pm 0.5$ & 2.0 & $1.0-2.0$ & 0.010 \\
\hline Total score & $9.0 \pm 1.1$ & 9.0 & $8.0-11.0$ & $5.7 \pm 1.5$ & 6.0 & $4.0-7.0$ & $5.5 \pm 1.0$ & 5.5 & $4.0-7.0$ & 0.003 \\
\hline
\end{tabular}

LMWH: Low molecular weight heparin; SD: Standard deviation; Min: Minimum; Max: Maximum. 
TABLE II

Statistical analyses of Movin's scale results

\begin{tabular}{|c|c|c|c|c|c|c|c|c|c|c|}
\hline \multirow[b]{2}{*}{ Movin's scale } & \multicolumn{3}{|c|}{ Control group } & \multicolumn{3}{|c|}{ Rivaroxaban group } & \multicolumn{3}{|c|}{ LMWH group } & \multirow[b]{2}{*}{$p$} \\
\hline & Mean \pm SD & Median & Min-Max & Mean \pm SD & Median & Min-Max & Mean $\pm S D$ & Median & Min-Max & \\
\hline Fiber structure & $2.0 \pm 0.0$ & 2.0 & $2.0-2.0$ & $1.2 \pm 0.4$ & 1.0 & $1.0-2.0$ & $1.7 \pm 0.5$ & 2.0 & $1.0-2.0$ & 0.015 \\
\hline Fiber alignment & $1.8 \pm 0.4$ & 2.0 & $1.0-2.0$ & $1.3 \pm 0.5$ & 1.0 & $1.0-2.0$ & $1.7 \pm 0.5$ & 2.0 & $1.0-2.0$ & 0.213 \\
\hline Nuclear roundness & $1.7 \pm 0.5$ & 2.0 & $1.0-2.0$ & $1.2 \pm 0.4$ & 1.0 & $1.0-2.0$ & $1.0 \pm 0.0$ & 1.0 & $1.0-1.0$ & 0.033 \\
\hline $\begin{array}{l}\text { Regional variation of } \\
\text { cellularity }\end{array}$ & $2.0 \pm 0.0$ & 2.0 & $2.0-2.0$ & $1.3 \pm 0.5$ & 1.0 & $1.0-2.0$ & $1.2 \pm 0.4$ & 1.0 & $1.0-2.0$ & 0.012 \\
\hline Vascularity increase & $3.0 \pm 0.0$ & 3.0 & $3.0-3.0$ & $1.8 \pm 1.0$ & 1.5 & $1.0-3.0$ & $1.7 \pm 0.5$ & 2.0 & $1.0-2.0$ & 0.010 \\
\hline $\begin{array}{l}\text { Decrease in collagen } \\
\text { stainability }\end{array}$ & $2.2 \pm 0.4$ & 2.0 & $2.0-3.0$ & $1.2 \pm 0.4$ & 1.0 & $1.0-2.0$ & $1.2 \pm 0.4$ & 1.0 & $1.0-2.0$ & 0.004 \\
\hline Hyalinization & $1.5 \pm 0.5$ & 1.5 & $1.0-2.0$ & $1.2 \pm 0.4$ & 1.0 & $1.0-2.0$ & $1.2 \pm 0.4$ & 1.0 & $1.0-2.0$ & 0.351 \\
\hline GAG content & $2.2 \pm 0.4$ & 2.0 & $2.0-3.0$ & $1.7 \pm 0.5$ & 2.0 & $1.0-2.0$ & $1.5 \pm 0.5$ & 1.5 & $1.0-2.0$ & 0.096 \\
\hline Total score & $16.3 \pm 1.5$ & 16.0 & $15.0-19.0$ & $10.8 \pm 2.6$ & 11.0 & $8.0-14.0$ & $11.0 \pm 2.3$ & 11.0 & $8.0-15.0$ & 0.004 \\
\hline
\end{tabular}

LMWH: Low molecular weight heparin; SD: Standard deviation; Min: Minimum; Max: Maximum; GAG: Glycosaminoglycan.

TABLE III

Statistical analysis of type I/ type III collagen measures with Sirius Red staining

\begin{tabular}{|c|c|c|c|c|c|c|c|c|c|c|}
\hline \multirow[b]{2}{*}{ Collagen } & \multicolumn{3}{|c|}{ Control group } & \multicolumn{3}{|c|}{ Rivaroxaban group } & \multicolumn{3}{|c|}{ LMWH group } & \multirow[b]{2}{*}{$p$} \\
\hline & Mean $\pm S D$ & Median & Min-Max & Mean $\pm S D$ & Median & Min-Max & Mean $\pm S D$ & Median & Min-Max & \\
\hline Type I & $28.3 \pm 5.2$ & 30.0 & $20.0-35.0$ & $67.5 \pm 7.6$ & 67.5 & $60.0-80.0$ & $71.7 \pm 6.8$ & 70.0 & $65.0-80.0$ & 0.002 \\
\hline Type III & $71.7 \pm 5.2$ & 70.0 & $65.0-80.0$ & $32.5 \pm 7.6$ & 32.5 & $20.0-40.0$ & $28.3 \pm 6.8$ & 30.0 & $20.0-35.0$ & 0.002 \\
\hline
\end{tabular}

LMWH: Low molecular weight heparin; SD: Standard deviation; Min: Minimum; Max: Maximum.

and Mann-Whitney $\mathrm{U}$ tests and parametric results of biomechanical tests were analyzed with analysis of variance. Statistical analyses were performed using the IBM SPSS version 22.0 (IBM Corp., Armonk, NY, USA) and statistical significance value was set as $\mathrm{p}<0.05$.

\section{RESULTS}

Bonar's scale total score was significantly higher in control group in comparison with both rivaroxaban

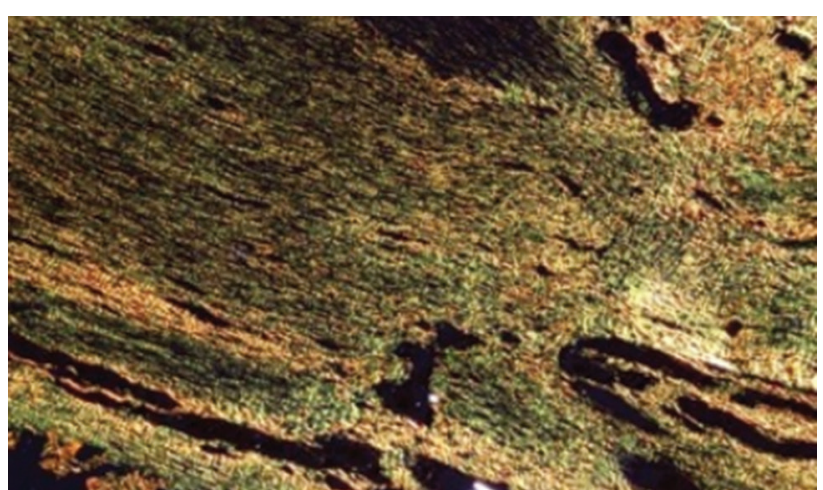

Figure 3. Type I/type III collagen staining pattern at histochemical staining with Sirius Red (type I collagen fibers appear thicker and orange-red in color; type III collagen fibers appear thinner and matte green in color). Control 6, $\times 100$, Sirius Red staining. and LMWH groups $(\mathrm{p}<0.05)$. Rivaroxaban and LMWH groups' Bonar's scale total scores were not significantly different ( $p>0.05$ ) from each other (Table I).

Movin's scale total score was significantly higher in control group in comparison with both rivaroxaban and LMWH groups $(\mathrm{p}<0.05)$. Rivaroxaban and LMWH groups' Movin's scale total scores were not significantly different ( $p>0.05)$ from each other (Table II).

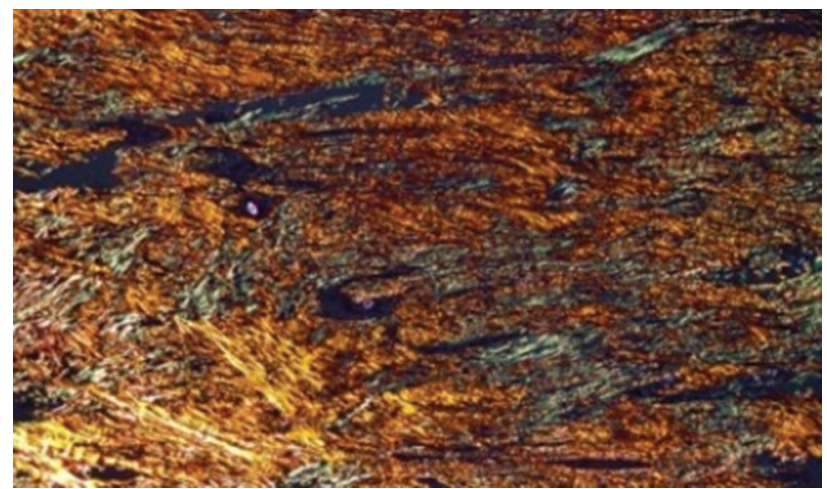

Figure 4. Type I/type III collagen staining pattern at histochemical staining with Sirius Red (type I collagen fibers appear thicker and orange-red in color; type III collagen fibers appear thinner and matte green in color). Rivaroxaban 4, ×100, Sirius Red staining. 


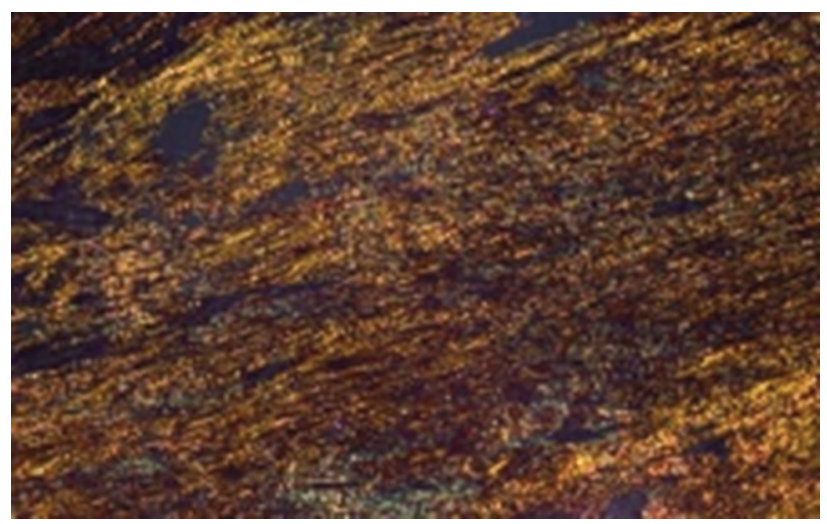

Figure 5. Type I/type III collagen staining pattern at histochemical staining with Sirius Red (type I collagen fibers appear thicker and orange-red in color; type III collagen fibers appear thinner and matte green in color). Low molecular weight heparin $3, \times 100$, Sirius Red staining.

Measure of type I collagen (mature collagen) was significantly lower in control group in comparison with both rivaroxaban and LMWH groups $(\mathrm{p}<0.05)$. There was no significant difference between rivaroxaban and LMWH groups according to type I collagen measures $(p>0.05)$ (Table III) (Figures 3, 4, and 5). On the contrary, type III collagen (immature collagen) measures were significantly higher in the control group in comparison with both rivaroxaban and LMWH groups $(\mathrm{p}<0.05)$. There was no significant difference between rivaroxaban and LMWH groups according to type III collagen measures $(p>0.05)$ (Table III).

Mean maximum rupture force in the control, rivaroxaban and LMWH groups were $30.08 \mathrm{~N}$, $22.16 \mathrm{~N}$ and $18.03 \mathrm{~N}$, respectively (Figure 6). There was no significant difference between control and rivaroxaban groups $(\mathrm{p}=0.18)$ according to mean maximum rupture force. However, mean maximum rupture force difference was significant between control and LMWH groups ( $\mathrm{p}=0.03$ ). Mean maximum rupture force was higher in the rivaroxaban group in comparison with LMWH group, but this difference was not statistically significant $(\mathrm{p}=0.31)$.

\section{DISCUSSION}

Tendon surgeries are frequently performed in daily orthopedic practice. Tendon healing, particularly Achilles tendon healing, is a slow process. As tendons heal via fibrotic scar tissue, it is essential to know the effects of the drugs on tendon healing process. ${ }^{[14]}$

Tatari et al. ${ }^{[17]}$ administered corticosteroid to rats' Achilles tendons and produced Achilles tendinitis; then, they administered local heparin to normal

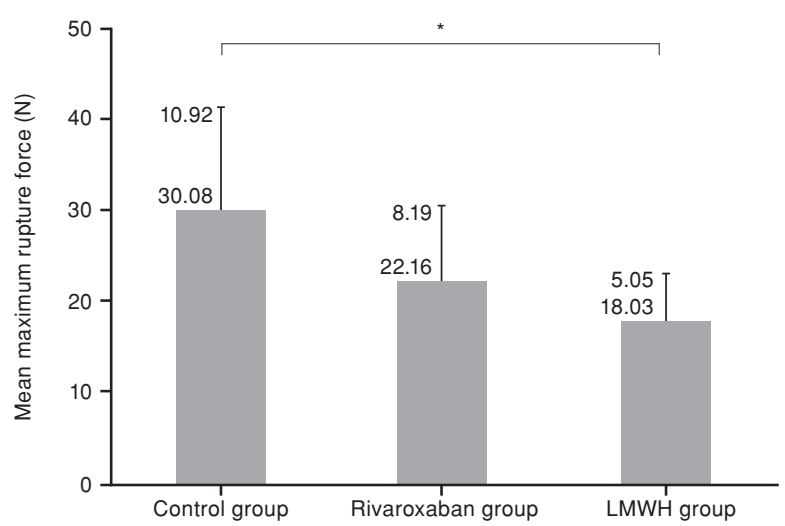

Figure 6. Mean maximum rupture force values obtained during tensile test on tendons. Groups with significant difference * $p<0.05$; LMWH: Low molecular weight heparin.

Achilles tendons and to tendons with tendinitis. Consequently, they reported that heparin caused degeneration on tendons in both groups.

Tendon healing is a complex process consisting of cell proliferation, angiogenesis, extracellular matrix production, remodeling and maturation ensuing each other. Growth factors are also effective on tendon healing. Like other tissues, after tendon injury, first hematoma and then fibrin coagulum occurs. In this coagulum; blood cells, thrombocytes and fibronectin are destructed. Healing process starts as local growth hormones migrate to the area with the effect of chemotactic factors released after destruction. ${ }^{[14,18,19]}$ Fibrin formation occurs via thrombin. It is hypothesized that antithrombotic agents impair particularly the initial step of the healing process through inhibiting fibrin formation.

Virchenko et al. ${ }^{[13]}$ demonstrated that antifactor Xa activity is peaked in two hours after injection and gets back to normal after 12 hours. In their study, they found that heparin administration via mini pump affected tendon healing adversely, but this adverse effect was not seen in the other two groups (the groups that heparin was administered single dose prior to surgery and via injection twice a day). ${ }^{[13]}$ In our study, single dose administration of both rivaroxaban and LMWH did not inhibit production of thrombin or fibrin continuously. We assume that fibrin coagulum formation at the healing area decelerated, blood supply increased and migration of growth factors accelerated with the impact of the drugs we administered. Furthermore, neovascularization and microcirculation enhancing effects of the agents used in the study induced enhancement and acceleration of healing. It has 
been reported that heparin and its derivatives accelerate healing by decreasing destruction in cells and tissues, increasing neovascularization, enhancing granulation, epithelialization and revascularization. ${ }^{[20,21]}$

In their study investigating the effect of LMWH on rat Achilles tendon healing, Esen et al ${ }^{[12]}$ demonstrated that high-dose LMWH (170 AXa) administration had a more positive effect on histopathological healing in comparison to low dose LMWH (85 AXa) administration. Furthermore, healing was significantly better both in high dose LMWH group and low dose LMWH group in comparison to control group. In our study, high-dose LMWH was administered. Bonar's scale total scores' and Movin's scale total scores' statistical analysis revealed that both drugs affected tendon healing positively according to control group; thus our findings support the results of Esen et al.'s study. ${ }^{[12]}$ In our study, type I and type III collagen ratio was examined via Sirius Red staining. Type I collagen, which appears more in mature tendon ultrastructure, was significantly higher in groups that received rivaroxaban or LMWH in comparison to control group.

Moreover, Esen et al. ${ }^{[12]}$ examined biomechanical results on the fourth week of tendon healing and found that maximum rupture force values ranged from high to low in the following order; high dose LMWH group, low dose LMWH group and control group. This difference was significant for high dose LMWH group.

Tensile test results obtained in our study showed higher maximum rupture force value in control group in comparison with rivaroxaban and LMWH groups; however, this finding was significant only between control group and LMWH group (Figure 6). As the studies evaluated different phases of tendon healing, our biomechanical findings did not correlate with Esen's biomechanical findings.

When histopathological results were considered, it was demonstrated that both rivaroxaban and LMWH groups had an accelerated healing process according to control group; on the contrary, positive effects on tendon healing were not shown clearly with biomechanical results. Discrepancy between biomechanical and histopathological findings may be attributed to short duration of our study and organization step, since tendon healing could not occur because of the short duration. Besides, the number of rats for each group may not be adequate to demonstrate the correlation between biomechanical and histopathological results.
Our study has some limitations. The study had an experimental design; hence we were unable to make comparisons in terms of clinical and functional outcomes. Achilles tendon ruptures in humans occur usually on degenerative basis; and in our study, we performed iatrogenic cuts on healthy rat tendons and repaired them. Thus, interpretation of our results as same as human Achilles tendon ruptures results may lead to misapprehension. Furthermore, we did not conduct dose adjustment for the drugs we used; also, we did not study the anti-factor Xa levels. We determined doses according to prior studies. Hence, we could not know the degree and the duration of fibrin coagulum inhibition particularly in the initial phase of healing. As we did not investigate early- and late-term outcomes separately, histopathological and biomechanical effects of the drugs on the late phases of healing were not evaluated.

In conclusion, both rivaroxaban and LMWH showed positive effects on tendon healing in histopathological assessments; however, the same outcomes were not obtained in biomechanical assessments. Both rivaroxaban and LMWH may be used in order to reduce the risk of DVT during the conservative or surgical treatment of Achilles tendon ruptures. Nevertheless, further randomized controlled studies on humans are needed to establish explicit deductions.

\section{Declaration of conflicting interests}

The authors declared no conflicts of interest with respect to the authorship and/or publication of this article.

\section{Funding}

The authors received no financial support for the research and/or authorship of this article.

\section{REFERENCES}

1. Huttunen TT, Kannus P, Rolf C, Felländer-Tsai L, Mattila VM. Acute achilles tendon ruptures: incidence of injury and surgery in Sweden between 2001 and 2012. Am J Sports Med 2014;42:2419-23.

2. Cooper MT. Acute Achilles Tendon Ruptures: Does Surgery Offer Superior Results (and Other Confusing Issues)? Clin Sports Med 2015;34:595-606.

3. Lassen MR, Borris LC, Nakov RL. Use of the low-molecularweight heparin reviparin to prevent deep-vein thrombosis after leg injury requiring immobilization. N Engl J Med 2002;347:726-30.

4. Nilsson-Helander K, Thurin A, Karlsson J, Eriksson BI. High incidence of deep venous thrombosis after Achilles tendon rupture: a prospective study. Knee Surg Sports Traumatol Arthrosc 2009;17:1234-8.

5. Patel A, Ogawa B, Charlton T, Thordarson D. Incidence of deep vein thrombosis and pulmonary embolism after Achilles tendon rupture. Clin Orthop Relat Res 2012;470:270-4. 
6. Makhdom AM, Cota A, Saran N, Chaytor R. Incidence of symptomatic deep venous thrombosis after Achilles tendon rupture. J Foot Ankle Surg 2013;52:584-7.

7. Falck-Ytter Y, Francis CW, Johanson NA, et al. Prevention of VTE in Orthopedic Surgery Patients. Antithrombotic Therapy and Prevention of Thrombosis (9th edition): American College of Chest Physicians Evidence-Based Clinical Practice Guidelines. Chest 2012;141:278-325.

8. Calder JD, Freeman R, Domeij-Arverud E, van Dijk CN, Ackermann PW. Meta-analysis and suggested guidelines for prevention of venous thromboembolism (VTE) in foot and ankle surgery. Knee Surg Sports Traumatol Arthrosc 2016;24:1409-20.

9. Taşkesen A, Ataoğlu B, Özer M, Demirkale İ, Turanli S. Glucosamine-chondroitin sulphate accelerates tendonto-bone healing in rabbits. Eklem Hastalik Cerrahisi 2015;26:77-83.

10. Aydın BK, Altan E, Acar MA, Erkoçak ÖF, Ugraş S. Effect of Ankaferd blood stopper ${ }^{\circledR}$ on tendon healing: an experimental study in a rat model of Achilles tendon injury. Eklem Hastalik Cerrahisi 2015;26:31-7.

11. Sarıkaya B, Yumuşak N, Yigin A, Sipahioğlu S, Yavuz Ü, Altay MA. Comparison of the effects of human recombinant epidermal growth factor and platelet-rich plasma on healing of rabbit patellar tendon. Eklem Hastalik Cerrahisi 2017;28:92-9.

12. Esen E, Cila E, Ozoğul C, Taşçi AG, Sipahioğlu S, Gemalmaz $\mathrm{HC}$, et al. The effect of low-molecular-weight heparin on rat tendon healing. [Article in Turkish] Acta Orthop Traumatol Turc 2009;43:54-61.

13. Virchenko O, Aspenberg P, Lindahl TL. Low molecular weight heparin impairs tendon repair. J Bone Joint Surg [Br] 2008;90:388-92.

14. Williams IF, Nicholls JS, Goodship AE, Silver IA. Experimental treatment of tendon injury with heparin. Br J Plast Surg 1986;39:367-72.

15. Movin T, Gad A, Reinholt FP, Rolf C. Tendon pathology in long-standing achillodynia. Biopsy findings in 40 patients. Acta Orthop Scand 1997;68:170-5.

16. Maffulli N, Longo UG, Franceschi F, Rabitti C, Denaro V. Movin and Bonar scores assess the same characteristics of tendon histology. Clin Orthop Relat Res 2008;466:1605-11.

17. Tatari H, Koşay C, Baran O, Ozcan O, Ozer E, Ulukuş C. Effect of heparin on tendon degeneration: an experimental study on rats. Knee Surg Sports Traumatol Arthrosc 2001;9:247-53.

18. Thomopoulos S, Soslowsky LJ, Flanagan CL, Tun S, Keefer CC, Mastaw J, et al. The effect of fibrin clot on healing rat supraspinatus tendon defects. J Shoulder Elbow Surg 2002;11:239-47.

19. Xia W, de Bock C, Murrell GA, Wang Y. Expression of urokinase-type plasminogen activator and its receptor is up-regulated during tendon healing. J Orthop Res 2003;21:819-25.

20. Hirsh J, Warkentin TE, Shaughnessy SG, Anand SS, Halperin JL, Raschke R, et al. Heparin and lowmolecular-weight heparin: mechanisms of action, pharmacokinetics, dosing, monitoring, efficacy, and safety. Chest 2001;119:64-94.

21. Kutlay J, Ozer Y, Isik B, Kargici H. Comparative effectiveness of several agents for preventing postoperative adhesions. World J Surg 2004;28:662-5. 